\title{
Restoration of Normal Conduction Properties in Demyelinated Spinal Cord Axons in the Adult Rat by Transplantation of Exogenous Schwann Cells
}

\author{
Osamu Honmou, Paul A. Felts, Stephen G. Waxman, and Jeffery D. Kocsis \\ Department of Neurology, Yale University School of Medicine, New Haven, Connecticut 06516, and PVAVEPVA \\ Neuroscience Research Center, VA Medical Center, West Haven, Connectıcut 06516
}

\begin{abstract}
Although remyelınation of demyelınated CNS axons is known to occur after transplantation of exogenous glial cells, previous studies have not determıned whether cell transplantation can restore the conduction properties of demyelınated axons in the adult CNS To examine this issue, the dorsal columns of the adult rat spınal cord were demyelınated by $x$-irradıatıon and ıntraspınal ınjectıons of ethıdıum bromıde Cell suspensıons of cultured astrocytes and Schwann cells derived from neonatal rats transfected with the ( $\beta$-galactosidase) reporter gene were injected into the glial-free lesion site After 3-4 weeks nearly all of the demyelınated axons were remyelınated by the transplanted Schwann cells The dorsal columns were removed and maintaıned in an in vitro recording chamber, conduction properties were studied usıng field potential and intra-axonal recording technıques The demyelınated axons exhıbited con-
\end{abstract}

duction slowing and block, and a reduction in their ability to follow high-frequency stımulation Axons remyelınated by transplantation of cultured Schwann cells exhibited restoration of conduction through the lesion, with reestablishment of normal conduction velocity The axons remyelınated after transplantation showed enhanced impulse recovery to paired-pulse stımulation and greater frequency-following capability as compared with both demyelınated and control axons These results demonstrate the functional repair of demyelınated axons in the adult CNS by transplantation of cultured myelın-formıng cells from the peripheral nervous system in combination with astrocytes

Key words demyelination, remyelination, cell transplantation, Schwann cells, astrocytes, restoration of conduction
Demyelination of axons in the CNS occurs in a number of neurological disorders including multiple sclerosis (MS) and contusive spinal cord injury (Blight, 1983, Byrne and Waxman, 1990, Bunge et al, 1993, McDonald, 1995) Even if the progression of MS were to be halted or slowed via immunotherapy, MS patients would contunue to harbor demyelmating lesions that produce significant functional deficits Cell transplantation has been suggested as a strategy for repair of demyelınated CNS axons (Blakemore and Crang, 1985, Groves et al , 1993, Vignais et al ,1993) In some experimental models of CNS demyelination, remyelination by endogenous oligodendrocytes (Gledhill et al, 1973, Gledhill and McDonald, 1977, Clifford-Jones et al , 1980) or by invasion of peripheral Schwann cells (Blakemore, 1976, Blakemore et al, 1977) occurs, with the reestablishment of relatively normal impulse conduction (Smith et al, 1979, 1981, Blight and Young, 1989, Felts and Smith, 1992), but permanent remyelination is very limited in humans (Ghatak et al , 1973, Prineas and Connell, 1979, Itoyama et al, 1985) Substantial anatomically defined myelınation can also be induced by transplantation of exogenous cultured glial cells derived from fetal or neonatal as well as adult anımals (Blakemore and Crang, 1985, Duncan et al, 1988, Rosenbluth et

\footnotetext{
Received Nov 10, 1995, revised Feb 7, 1996, dccepted Feb 12, 1996

This work was supported in part by grants from the National Multiple Sclerosis Society, National Institutes of Health, the Myelin Project, and the Medical Research Service of the Department of Veterans Affalis OH was supported in part by the $J$ M Foundation and by an EPVA Spinal Cord Research Fellowship PF was supported in part by a Multiple Sclerosis Fellowship from the EPVA

Correspondence should be addressed to Jeffery D Kocsis, Yalc University School of Medicine, Neuroscience Research Center (127A), VA Medical Center, West Haven, CT 06516

Copyright $\odot 1996$ Society for Neuroscience $0270-6474 / 96 / 163199-10 \$ 0500 / 0$
}

al , 1990, Gout and Dubors-Dalcq, 1993, Lachapelle et al , 1994) Moreover, human Schwann cells can produce compact myelın in an immunodeficient mouse mutant model (Lev1 and Bunge, 1994)

Oligodendrocyte remyelination subsequent to transplantation of CNS glial cell suspensions into the amyelinated immature myelindefictent mutant rat spinal cord ( $5 \mathrm{~d}$ old $)$ has been demonstrated to result in increased conduction velocity (Utzschneider et al, 1994) However, whereas it is known that compact myelin may be formed after transplantation of exogenous glial cells into demyelinated regions of adult CNS (Blakemore and Franklın, 1991), virtually no assessment of the electrophysiological properties of the remyelinated axons has been undertaken Such studies are important because reliable impulse conduction in remyelinated axons requires not only the formation of compact myelin but also the establıshment of appropriate myelin segment length (Huxley and Stampfli, 1949, Waxman and Brill, 1978) and on channel organization at the newly formed nodes of Ranvier (Ritchie and Rogart, 1977, Waxman, 1977, Moore et al, 1978, Hines and Shrager, 1991) It is not known whether remyelination by transplanted exogenous glial and Schwann cells, especially in the adult CNS, meets these criteria for the rcestablishment of normal conduction

To lest directly whether cultured exugenous Schwann cells interact with axons in the adult CNS after transplantation so as to reestablısh normal impulse conduction, we transplanted cultured neonatal Schwann cells, in some cases transfected with the LacZ reporter gene, and astrocytes derived from immature rats into the spinal cords of demyelinated adult rat spinal cord We report restoration of nearly normal conduction properties in axons of the adult rat spinal cord after remyelınation by transplanted, exogenously derived Schwann cells 

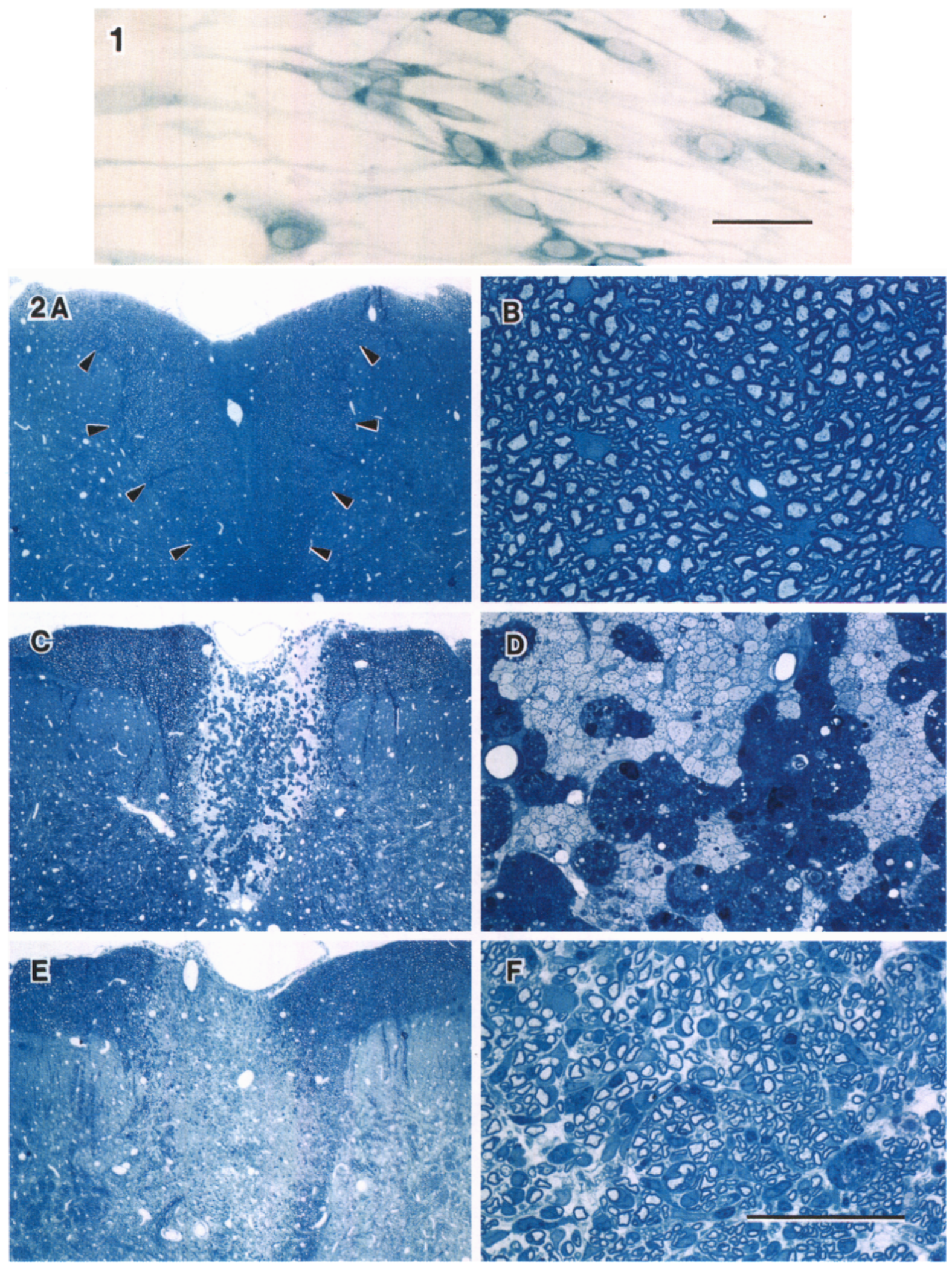

Figure 1. $\beta$-Gal gene products are detected as a blue color in neonatal sciatic nerve Schwann cells in vitro. Scale bar, $50 \mu \mathrm{m}$.

Figure 2. Low $(A, C, E)$ and high $(B, D, F)$ magnification light micrographs of transverse sections through the dorsal columns of normal $(A, B)$, demyelinated but untransplanted $(C, D ; 25 \mathrm{~d}$ after EB injection), and transplanted ( $E, F ; 24 \mathrm{~d}$ after EB injection) animals. In the absence of a transplant, the lesion (translucent region within the dorsal columns in $C$ ) is composed of naked, demyelinated axons and debris-filled phagocytes $(D)$. Transplantation of cultured Schwann cells and astrocytes results in a large region (light blue area within the dorsal columns in $E$ ) of Schwann cell-remyelinated axons $(F)$. For orientation at low magnification, the dorsal columns have been outlined with arrowheads in $A$. Scale bar: $A, C, E, 500 \mu \mathrm{m} ; B, D, F, 50 \mu \mathrm{m}$. 

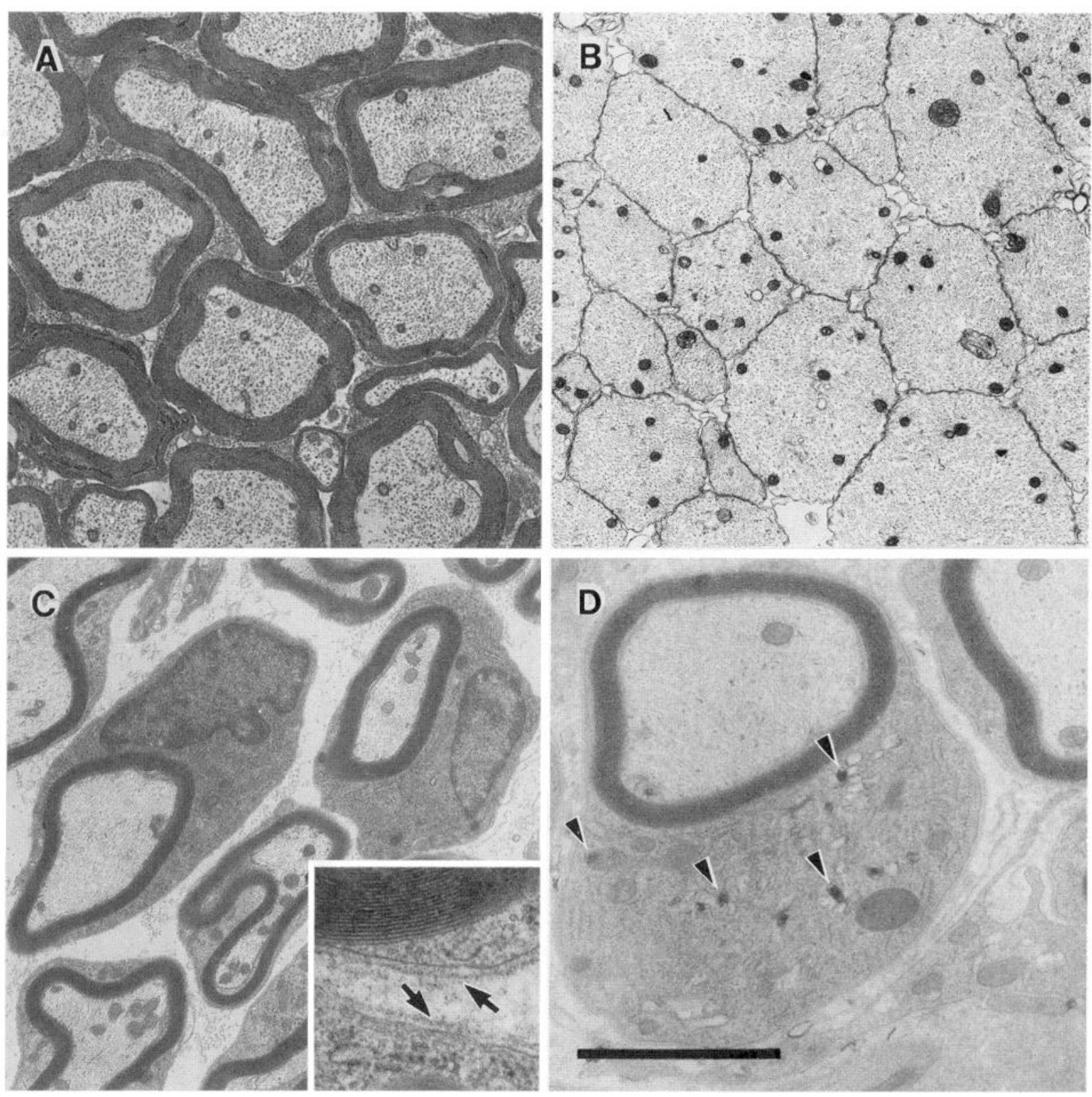

Figure 3. Electron micrographs showing normal $(A)$ and demyelinated $(B)$ axons in the dorsal columns. All demyelinated spinal cords that received cell injections showed clear evidence of remyelination $(C)$ of the demyelinated axons. Examination at higher magnification (inset in $C$ ) showed the presence of a basal lamina (arrows) as well as extracellular collagen fibrils surrounding the individual fibers, indicative of Schwann cell myelination. $D$, Schwann cells carrying the $\beta$-gal gene (reaction product indicated by arrowheads) could be detected in the lesion by treating the tissue with the substrate X-Gal. Scale bar: $A-C, 4 \mu \mathrm{m} ; D, 2 \mu \mathrm{m}$; inset in $C, 0.6 \mu \mathrm{m}$.

\section{MATERIALS AND METHODS}

Demyelination model ( $x$-ray irradiation and ethidium bromide injection). Rats were anesthetized with ketamine $(75 \mathrm{mg} / \mathrm{kg}$, i.p.) and xylazine (10 $\mathrm{mg} / \mathrm{kg}$, i.p.) and $\mathrm{x}$-irradiated utilizing a method similar to that of Blakemore and Patterson (1978). Briefly, a 40 Grays surface dose of $\mathrm{x}$-irradiation was delivered through a $2 \times 4 \mathrm{~cm}$ opening in a lead shield (4 mm thick) to the spinal cord caudal to T10 using a Siemens Stabilipan radiotherapy machine $(250 \mathrm{kV}, 15 \mathrm{~mA}, 0.5 \mathrm{~mm} \mathrm{Cu}$, and $1.0 \mathrm{~mm}$ Al filters, SSD $28 \mathrm{~cm}$, dose rate $220.9 \mathrm{cGy} / \mathrm{min}$; Siemans AG, Erlangen, Germany). Three days after irradiation, rats were anesthetized as above and, using sterile technique, a laminectomy was performed at T11. The demyelinating lesion was induced by the direct injection of ethidium bromide (EB), a nucleic acid-chelating agent that induces primary demyelination by killing oligodendrocytes, into the dorsal columns via a drawn glass micropipette. Injections of $0.5 \mu \mathrm{l}$ of $0.3 \mathrm{mg} / \mathrm{ml} \mathrm{EB}$ in saline were made at depths of 0.7 and $0.4 \mathrm{~mm}$ at three longitudinal sites $2 \mathrm{~mm}$ apart for a total of six injections.
Primary cell culture, transfection of $L a c Z$ gene, and cell transplantation. Primary Schwann cell cultures were established from the sciatic nerve of neonatal rats (P1-P3) according to the method of Brockes et al. (1979). Briefly, the cell suspension resulting from enzymatically and mechanically dissociating sciatic nerves was plated onto $100 \mathrm{~mm}^{2}$ poly-L-lysine-coated tissue culture plates at $8 \times 10^{5}$ cells per plate and cultured in DMEM supplemented with $10 \%$ (v/v) fetal calf serum (Fig. 1).

Primary astrocyte cell cultures were established from the neonatal rat optic nerve based on the method of McCarthy et al. (1980). After enzymatic and mechanical dissociation, cells were plated onto $100 \mathrm{~mm}^{2}$ poly-L-lysine-coated tissue culture plates at $8 \times 10^{5}$ cells per plate and cultured in minimum essential media (MEM) supplemented with $15 \%$ $(\mathrm{v} / \mathrm{v})$ fetal calf serum.

A replication-defective retrovirus vector was used to transduce the bacterial $\beta$-galactosidase ( $\beta$-gal) gene into primary cultures of Schwann cells. Schwann cells were transfected by the BAG retroviral vector (Price et al., 1987) contained in the $\Psi 2$ packaging line (Mann et al., 


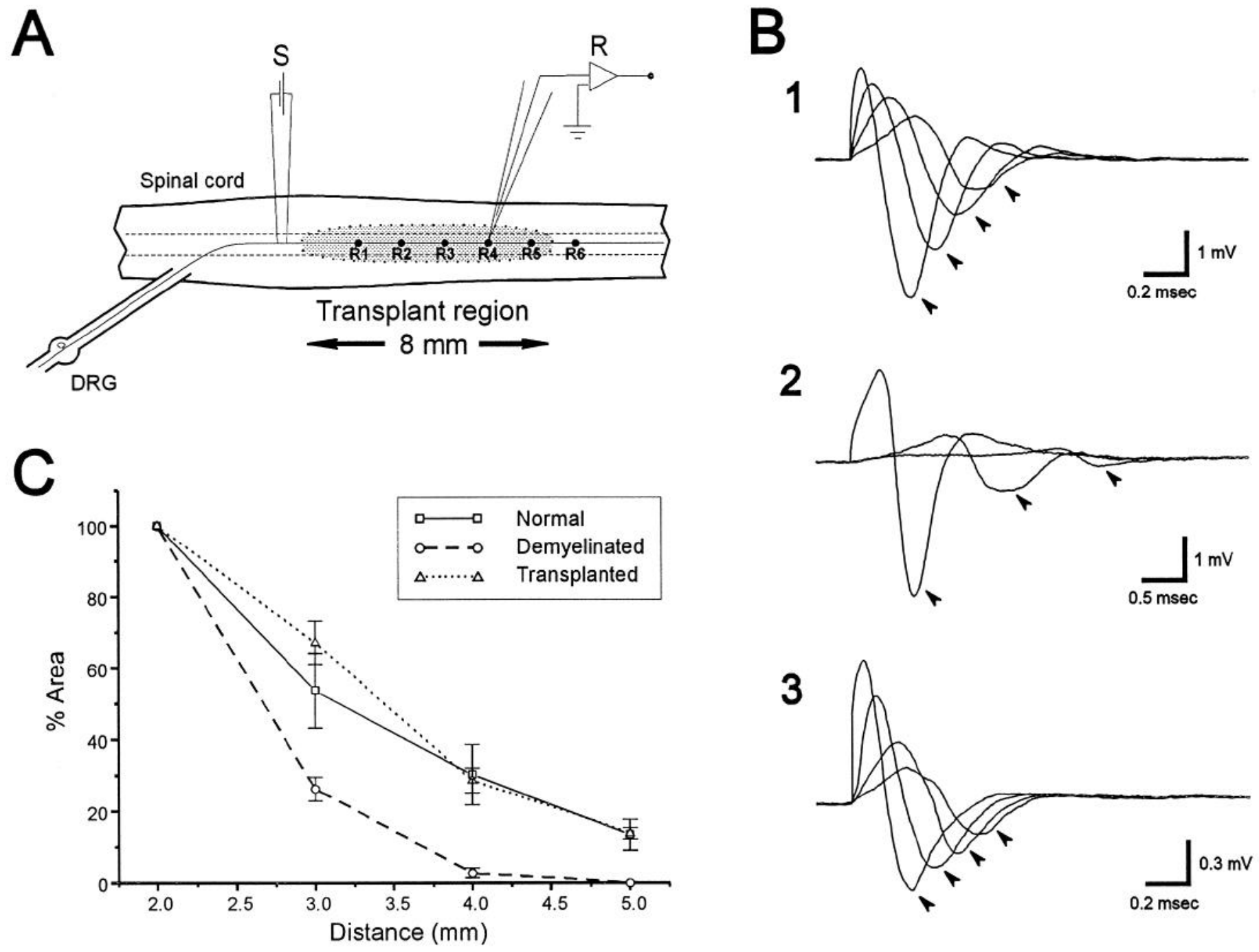

Figure 4. A, Schematic showing the dorsal surface of spinal cord with the positions of the stimulating $(S)$ and recording $(R)$ electrodes. Shaded region indicates the area of demyelination or remyelination. $B$, Compound action potentials recorded at $1 \mathrm{~mm}$ increments along the dorsal columns in control (1), EB-X-demyelinated (2), and transplant-induced remyelinated (3) axons. $C$, Compound action potential area (\% Area) plotted versus conduction distance for normal, demyelinated, and transplant-induced remyelinated dorsal columns $(n=5)$.

1983). The BAG vector is constructed by cloning the $\beta$-gal gene into the pDOL vector derived from the Maloney murine leukemia virus (Mo-MuLV). The wild-type Mo-MuLV LTR provided the promoter for the $\beta$-gal gene. The simian virus 40 early promoter and the Tn5 neomycin-resistance gene, transmitting G418 resistance, are present downstream from the $\beta$-gal gene to permit selection of infected colonies. Supernatants from packaging cells were used, in the presence of polybrene $(8 \mu \mathrm{g} / \mathrm{ml})$, to infect cultured Schwann cells, which were rapidly proliferating under the influence of $2 \mu \mathrm{M}$ forskolin and glial growth factor (Brockes et al., 1979). Before transfection, contaminating fibroblasts were eliminated by treatments with the antimitotic agent cytosine arabinoside $(10 \mu \mathrm{M})$ and antibody-complement-mediated cell lysis using the monoclonal anti-Thy 1.1 antibody and rabbit complement (Porter et al., 1986). Transfected Schwann cells were then selected by incubation with neomycin analog G418 $(400 \mu \mathrm{g} / \mathrm{ml})$. Under ketamine/xylazine anesthesia, a suspension of $5 \times 10^{4}$ Schwann cells and astrocytes $(\sim 3 / 2)$ in $1 \mu \mathrm{l}$ of DMEM was injected into the middle of the EB-X-induced lesion $3 \mathrm{~d}$ after the EB injection.

Histological examination. The rats were deeply anesthetized with sodium pentobarbital $(50 \mathrm{mg} / \mathrm{kg}$, i.p.) and perfused through the heart, first with PBS at room temperature and then with a fixative solution containing $2 \%$ glutaraldehyde and $2 \%$ paraformaldehyde in $0.14 \mathrm{M}$ Sorensen's phosphate buffer, $\mathrm{pH}$ 7.4. After in situ fixation for $10 \mathrm{~min}$, the spinal cord was carefully excised, cut into $1 \mathrm{~mm}$ segments, and placed in fresh fixative. The tissue was washed several times in Sorensen's buffer, post-fixed with
$1 \% \mathrm{OsO}_{4}$ for $2 \mathrm{hr}$ at $25^{\circ} \mathrm{C}$, dehydrated in graded ethanol solutions, passed through propylene oxide, and embedded in Epon. After polymerization at $60^{\circ} \mathrm{C}$, thick sections $(1 \mu \mathrm{m})$ were cut, counterstained with $0.5 \%$ methylene blue, $0.5 \%$ azure II in $0.5 \%$ borax, and examined with a light microscope. Thin sections were counterstained with uranyl and lead salts and examined with a Zeiss EM902A electron microscope operating at $80 \mathrm{kV}$.

Detection of $\beta$-gal reaction products in vitro and in vivo. $\beta$-Galexpressing cells were detected in vitro by incubating the cultured Schwann cells with X-Gal to form a blue color within the cell (Fig. 1). Schwann cells were fixed in $0.05 \%$ glutaraldehyde, washed with PBS, and then incubated with X-Gal to a final concentration of $1 \mathrm{mg} / \mathrm{ml}$ in X-Gal developer $\left(35 \mathrm{~mm} \mathrm{~K}{ }_{3} \mathrm{Fe}(\mathrm{CN})_{6} / 35 \mathrm{mM} \mathrm{K}_{4} \mathrm{Fe}(\mathrm{CN})_{6}{ }^{3} \mathrm{H}_{2} \mathrm{O} / 2 \mathrm{mM} \mathrm{MgCl}\right.$ in PBS). Cells were incubated at $37^{\circ} \mathrm{C}$ overnight and examined by light microscopy for the presence of a blue reaction product. Over $99 \%$ of cells were marked by the $L a c Z$ gene. The presence of helper virus in the tissue culture medium was also assayed according to the method of Price et al. (1987); supernatants from transfected Schwann cells were not able to infect NIH3T3 cells.

Three weeks after transplantation, $\beta$-gal-expressing Schwann cells were detected in vivo. Spinal cords were removed and fixed in $0.5 \%$ glutaraldehyde in phosphate buffer for $1 \mathrm{hr}$. Sections $(100 \mu \mathrm{m})$ were cut with a vibratome, and $\beta$-gal-expressing Schwann cells were detected by incubating the sections at $37^{\circ} \mathrm{C}$ overnight with X-Gal to a final concentration of $1 \mathrm{mg} / \mathrm{ml}$ in X-Gal developer to form a blue color within the cell. The slices were then fixed for an additional $3 \mathrm{hr}$ in $3.6 \%$ (v/v) glutaraldehyde in 
Normal Demyelinated Transplanted
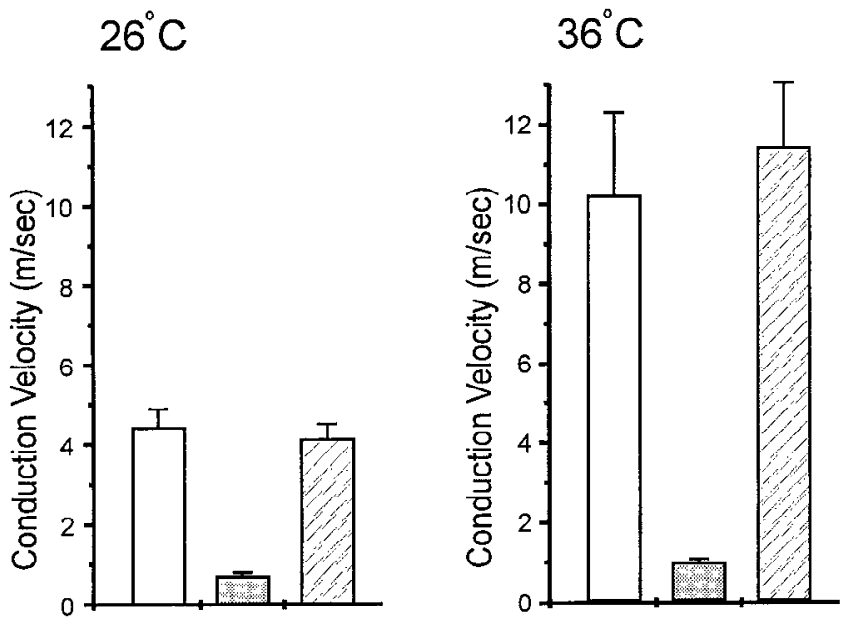

Figure 5. Conduction velocity for control, demyclinated, and remyelinated axons recorded at 26 and $36^{\circ} \mathrm{C}$. Error bars indicate SEM in this and subsequent figures.

phosphate buffer $(0.14 \mathrm{M})$. Before embedding in epon, the tissue was osmicated in $1 \% \mathrm{OsO}_{4}$, dehydrated in a graded series of ethanols, and infiltrated briefly with propylene oxide. Ultrathin sections were then examined in the electron microscope without further staining.

Field potential recording. After induction of deep anesthesia (sodium pentobarbital $50 \mathrm{mg} / \mathrm{kg}$, i.p.), the spinal cords of control, demyelinated, and transplanted rats were quickly removed and maintained in an in vitro submcrsion-typc recording chamber with a modified Krebs' solution (containing $124 \mathrm{~mm} \mathrm{NaCl}, 26 \mathrm{~mm} \mathrm{NaHCO}, 3 \mathrm{~mm} \mathrm{KCl}, 1.3 \mathrm{~mm} \mathrm{NaH}_{2} \mathrm{PO}_{4}$, $2 \mathrm{~mm} \mathrm{MgCl}, 10 \mathrm{~mm}$ dextrose, $2 \mathrm{mM} \mathrm{CaCl}$; saturated with $95 \% \mathrm{O}_{2} / 5 \%$ $\mathrm{CO}_{2}$ ). Field potential recordings of compound action potentials were obtained with glass microelectrodes $(1-5 \mathrm{M} \Omega ; 1 \mathrm{M} \mathrm{NaCl})$ positioned in the dorsal columns (Fig. $4 A$ ), and signals were amplified with a high input impedance amplifier and stored on a digital oscilloscope. The axons were activated by electrical stimulation of the dorsal columns with bipolar Teflon-coated stainless steel electrodes cut flush and placed lightly on the dorsal surface of the spinal cord. Constant current stimulation pulses were delivered through stimulus isolation units, and the timing of the pulses was controlled by a digital timing device. The recorded field potentials were positive-negative-positive waves corresponding to source-sink-source currents associated with propagating axonal action potentials (Kocsis and Waxman, 1980); the negativity represents inward current associated with the depolarizing phase of the action potential.

Intra-axonal recording. Intra-axonal recordings were obtained with borosilicate electrodes pulled on a Brown-Flaming P-80 puller and filled with $4 \mathrm{M} \mathrm{KAc}$ and $0.1 \mathrm{M} \mathrm{KCl}$. The DC resistances of the microelectrodes ranged from 100 to $150 \mathrm{M} \Omega$. Identification of intra-axonal recordings used criteria that have been discussed previously (Honmou et al., 1994). Impalements were considered to be intracellular if they displayed a resting potential greater than $-50 \mathrm{mV}$ with spike overshoot and if passage of a constant hyperpolarizing current caused an increase in action potential amplitude (Barrett and Barrett, 1982; Kocsis and Waxman, 1982; Blight and Someya, 1985; Kapoor et al., 1993). Dorsal column stimulation pulses were delivered through a bipolar, Teffon-coated, stainless steel stimulation electrode cut flush and placed directly on the dorsal column segment. Single axon stimulation pulses were delivered through the recording microelectrode and consisted of constant-current pulses (up to $0.5 \mathrm{nA}$ ) of up to $100 \mathrm{msec}$ duration provided by the step current command of the recording amplifier and monitored on a separate channel. An active bridge circuit was used to compensate for electrode and preparation resistance.

\section{RESULTS}

The dorsal columns of the normal adult rat consist largely of myelinated axons (Figs. 2A,B, 3A). The axons were demyelinated using the EB/X-irradiation (EB-X) lesion model; the axons in the lesion were virtually completely demyelinated, and the lesion site was largely glial-free (Figs. $2 C, D, 3 B$ ). The demyelinated lesions were large and well circumscribed, encompassing $70-80 \%$ of the transverse extent of the dorsal column and measuring 7-8 $\mathrm{mm}$ longitudinally. There was no evidence of remyelination by either oligodendrocytes or Schwann cells 1-6 weeks after lesion induction. The demyelinated axons within the lesion were clumped together, and macrophages filled with myelin debris were located between the naked axons. No axonal ensheathment was observed in the lesions. Unlike many experimentally induced demyelination models where endogenous remyclination commences within days of lesion induction, the glial-free zone remains intact for more than 5-6 weeks in the EB-X model. This offers experimental advantage in that transplanted cells can be introduced and remyelinate the demyelinated axons without competition from endogenous cells. Virtually all of the axons within the lesion zone were remyelinated by 3 weeks after Schwann cell and astrocyte transplantation (Figs. $2 E, F, 3 C$ ), with the exception of the very finest caliber axons, which likely represent normally unmyelinated axons. In some experiments Schwann cells were transfected with the $L a c Z$ reporter gene to confirm that the remyelination was indeed produced by transplanted cells (Fig. $3 D$ ).

In normal dorsal columns the negativity of the field potential increased in latency and decreased in amplitude with increasing conduction distance (Fig. 4B1,C). After $5 \mathrm{~mm}$ of conduction in control dorsal columns, the amplitude of the response was reduced to $13.4 \pm 4.4 \%$ (average $\pm \mathrm{SEM} ; n=5$ ) of the response recorded at $2 \mathrm{~mm}$. In the demyelinated axons, the amplitude decreased precipitously with increasing conduction distance (Fig. $\left.4 B 2, C^{\prime}\right)$, and virtually no impulse activity was observed at a distance of $5 \mathrm{~mm}$ from the stimulating electrode, indicating extensive conduction block in the demyelinated axons. In contrast, amplitude decrement with distance was indistinguishable from controls in transplanted dorsal columns (Fig. $4 B 3, C$ ), indicating that conduction was similar to normal, with action potentials propagating for a greater distance into the lesion than observed in demyelinated axons.

Conduction velocity was considerably reduced in the demyelinated axons at both 26 and $36^{\circ} \mathrm{C}$, and was restored to normal values at both temperatures after transplantation (Fig. 5); conduction velocity (at $36^{\circ} \mathrm{C}$ ) was $10.2 \pm 0.9 \mathrm{~m} / \mathrm{sec}(n=5)$ in control and $0.9 \pm 0.1 \mathrm{~m} / \mathrm{sec}(n=5)$ in the demyelinated dorsal columns. After transplant-induced remyelination, conduction velocity was restored to virtually the same values as in controls $(11.4 \pm 0.7$ $\mathrm{m} / \mathrm{sec}, n=5$ ). These results indicate that essentially normal conduction velocity is restored by remyelination induced by Schwann cell transplantation.

Conduction velocity was also studied in single axons that traversed the lesion site using intra-axonal recording techniques. Arrays of stimulating electrodes were placed on the spinal cord dorsum within the lesion and on the nondemyelinated dorsal column several millimeters away. Axons were then impaled at a site between the two arrays of stimulating electrodes within the nondemyelinated region, thus permitting study of conduction along segments of the same axon that included and excluded the lesion. In demyelinated spinal cords that had not received a transplant, the portion of the axon passing through the region of demyelination (Fig. 6B2) cxhibited considerably longer latencies indicative of slower conduction velocity than the nondemyelinated part of the same axon (Fig. 6BI). In contrast, in spinal cords that had received transplants, conduction velocity was virtually the 
same for fibers remyelinated by transplanted Schwann cells (Fig. $6 C 2$ ) as compared to conduction along their trajectory outside of the transplant region (Fig. 6C1). A plot of conduction velocity including the lesion versus conduction velocity excluding the lesion from each of the two experimental groups (demyelinated without transplant vs transplant-induced remyelinated) is shown in Figure $6 D$. The remyelinated axons have a conduction velocity that is substantially greater than in the demyelinated axons. Moreover, action potentials evoked from stimulation within the transplant region propagated into the nondemyelinated portion of the spinal cord (Fig. 6C2), demonstrating that axonal conduction occurred through the zone of potential impedance mismatch between the remyelinated region and normal region of the host nervous system.

Recovery properties of the axons were studied using pairedpulse stimulation (Fig. 7). In normal dorsal columns $\left(26^{\circ} \mathrm{C}\right)$, impulse activity was blocked for $\sim 2 \mathrm{msec}$ after the conditioning stimulus, and recovery began at $\sim 3$ msec. Full recovery of field potential amplitude was attained at $\sim 10 \mathrm{msec}$. The onset of recovery in the demyelinated axons was delayed as compared with control by $\sim 1 \mathrm{msec}$, but the slope of recovery was similar to control at $26^{\circ} \mathrm{C}$ (Fig. $7 \mathrm{D}$ ). Axons remyelinated after transplantation had a more rapid recovery than control axons. The onset of recovery occurred sooner, and the slope of recovery was greater. At $36^{\circ} \mathrm{C}$, recovery for all three groups of axons occurred earlier than at $26^{\circ} \mathrm{C}$, but the relative difference between control and demyelinated axons was increased, and the difference between control and remyelinated axons was smaller (Fig. $7 E$ ), although at $36^{\circ} \mathrm{C}$ the remyelinated axons still displayed recovery that was faster than in controls.

Another difference in conduction in the remyelinated axons was their enhanced ability to follow high-frequency stimulation; the demyelinated axons showed considerable reduction in the ability to follow high-frequency stimulation (Fig. 8). At both 26 and $36^{\circ} \mathrm{C}$, the fiber volley amplitude of the demyelinated axons was reduced compared with controls for stimulus trains at $50 \mathrm{~Hz}$ and higher. Frequency-response properties in remyelinated axons after transplantation were enhanced. Remyelinated axons were able to follow high-frequency stimulation as well as controls but exhibited less amplitude decrement at high stimulus frequencies than the control axons.

\section{DISCUSSION}

Functional repair of the CNS by cell transplantation has been considered as a potential therapeutic approach for a number of neurological disorders. Indeed, clinical studies introducing dopamine-producing cells into the caudate nucleus in humans have been underway for several years in patients with basal ganglia disorders (Lindvall et al., 1994). The prospect of introducing myelin-forming cells into patients with demyelinating
A
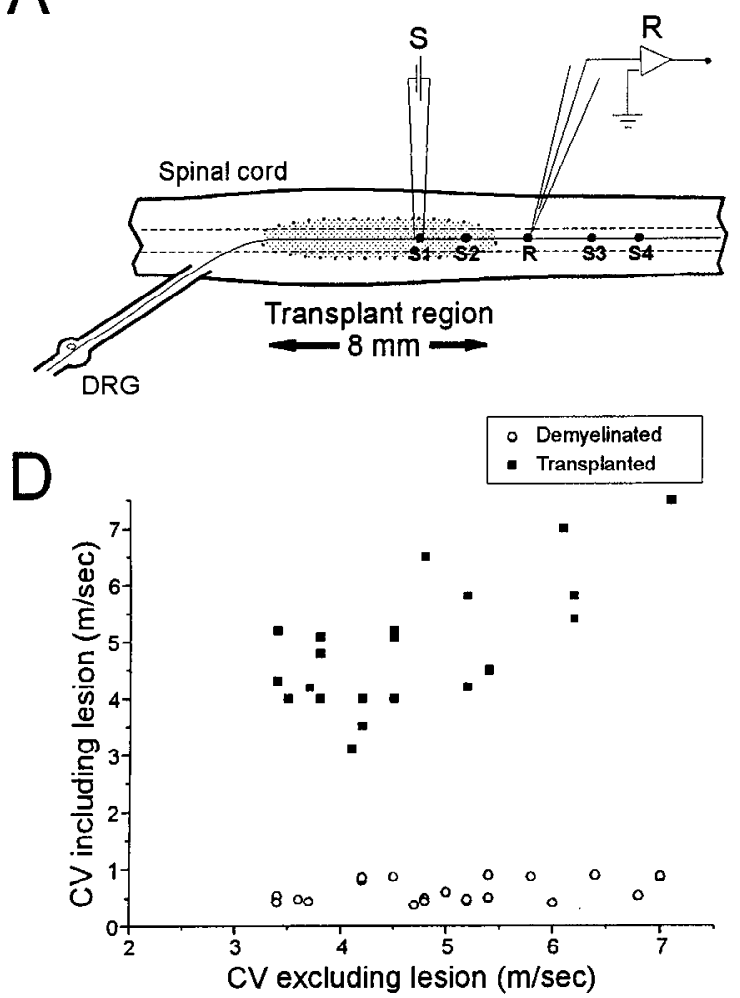

B
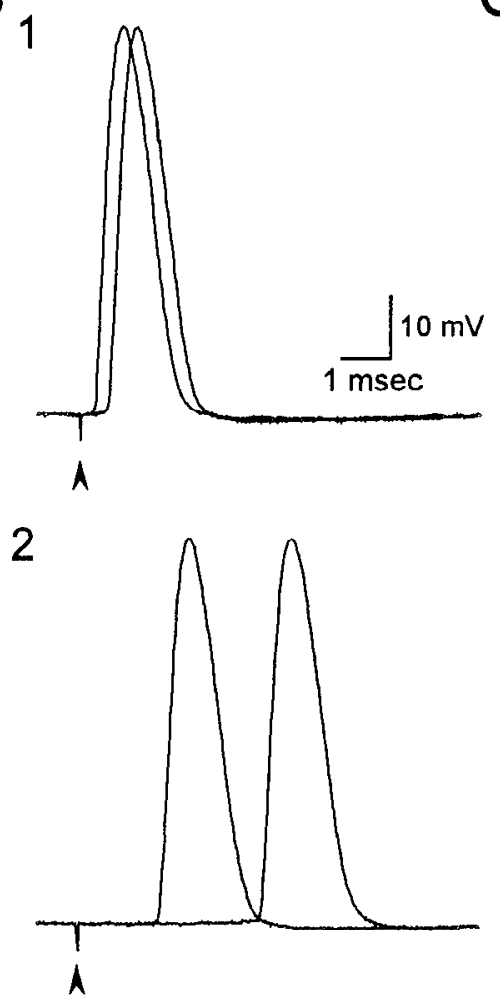

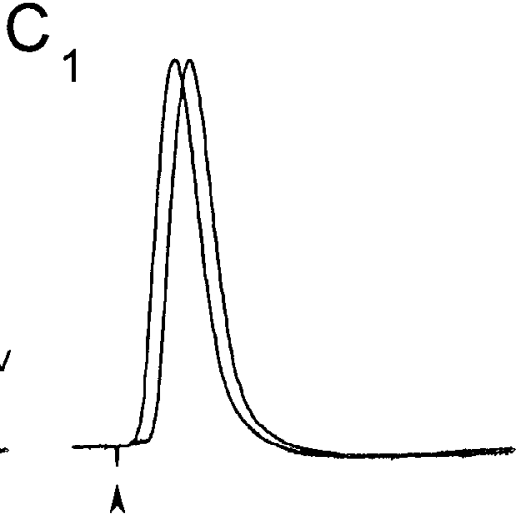

2

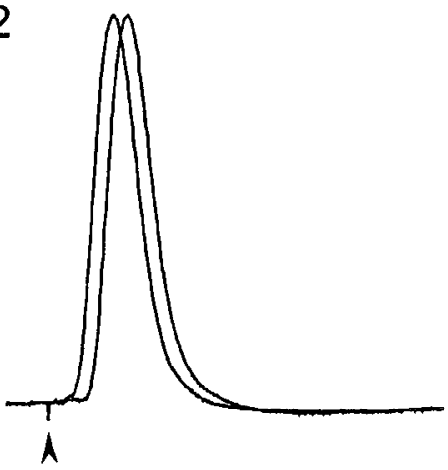

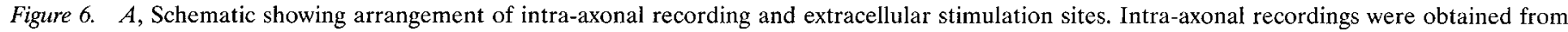

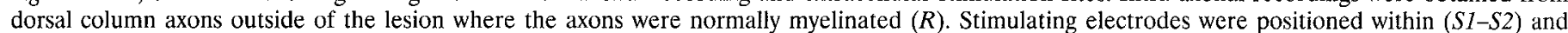

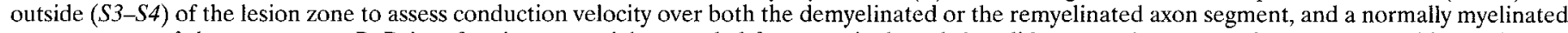

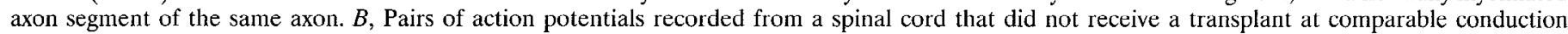

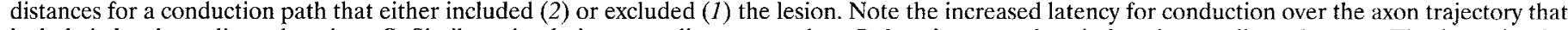

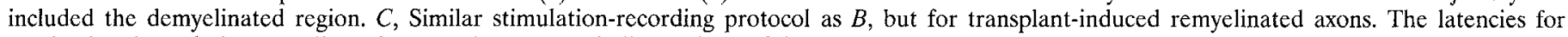

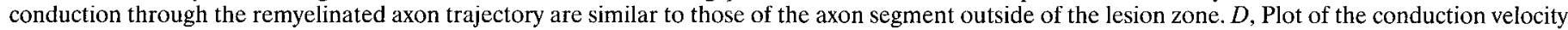

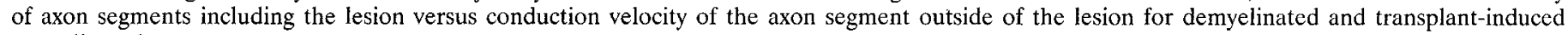
remyelinated groups. 

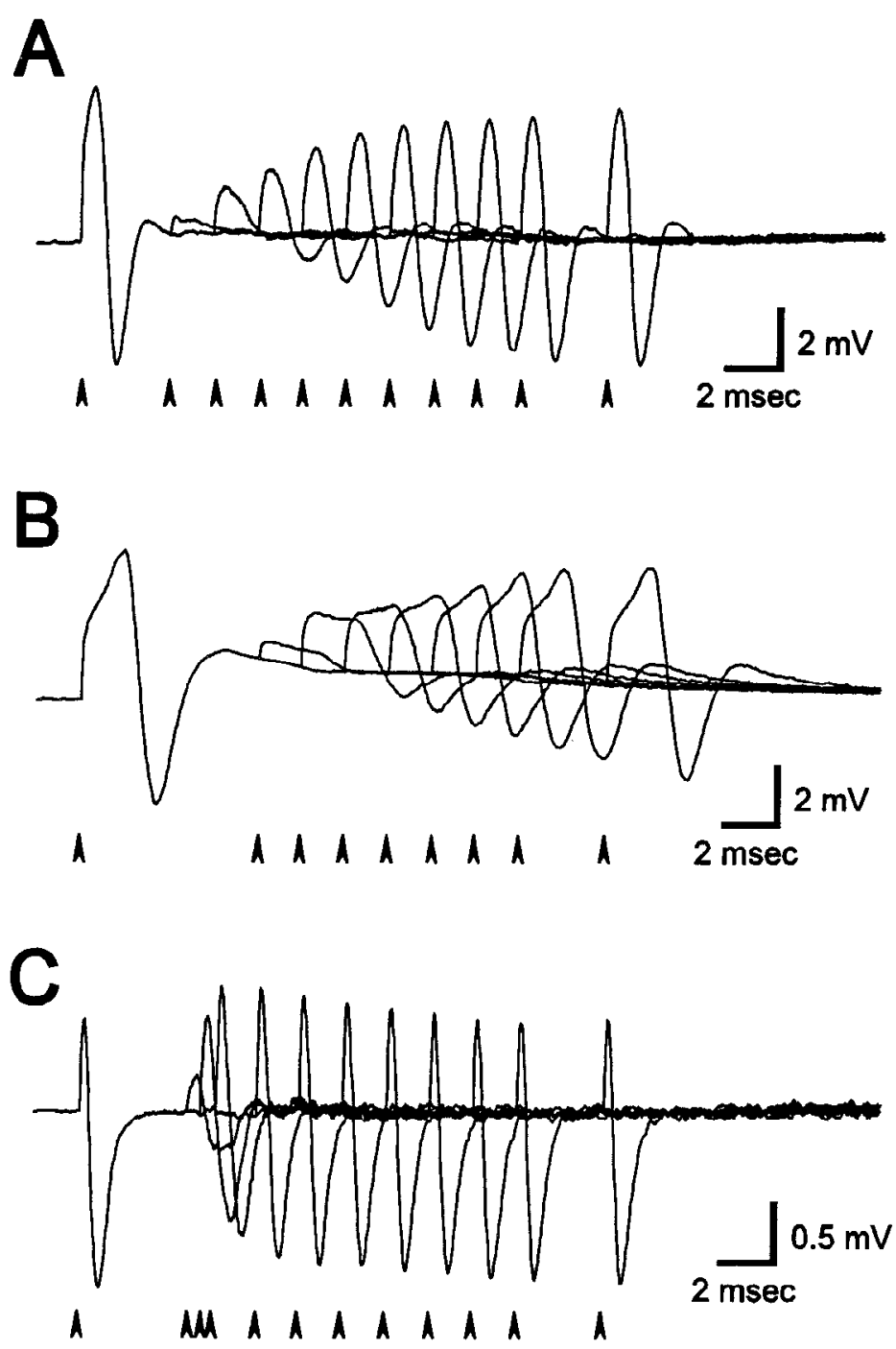
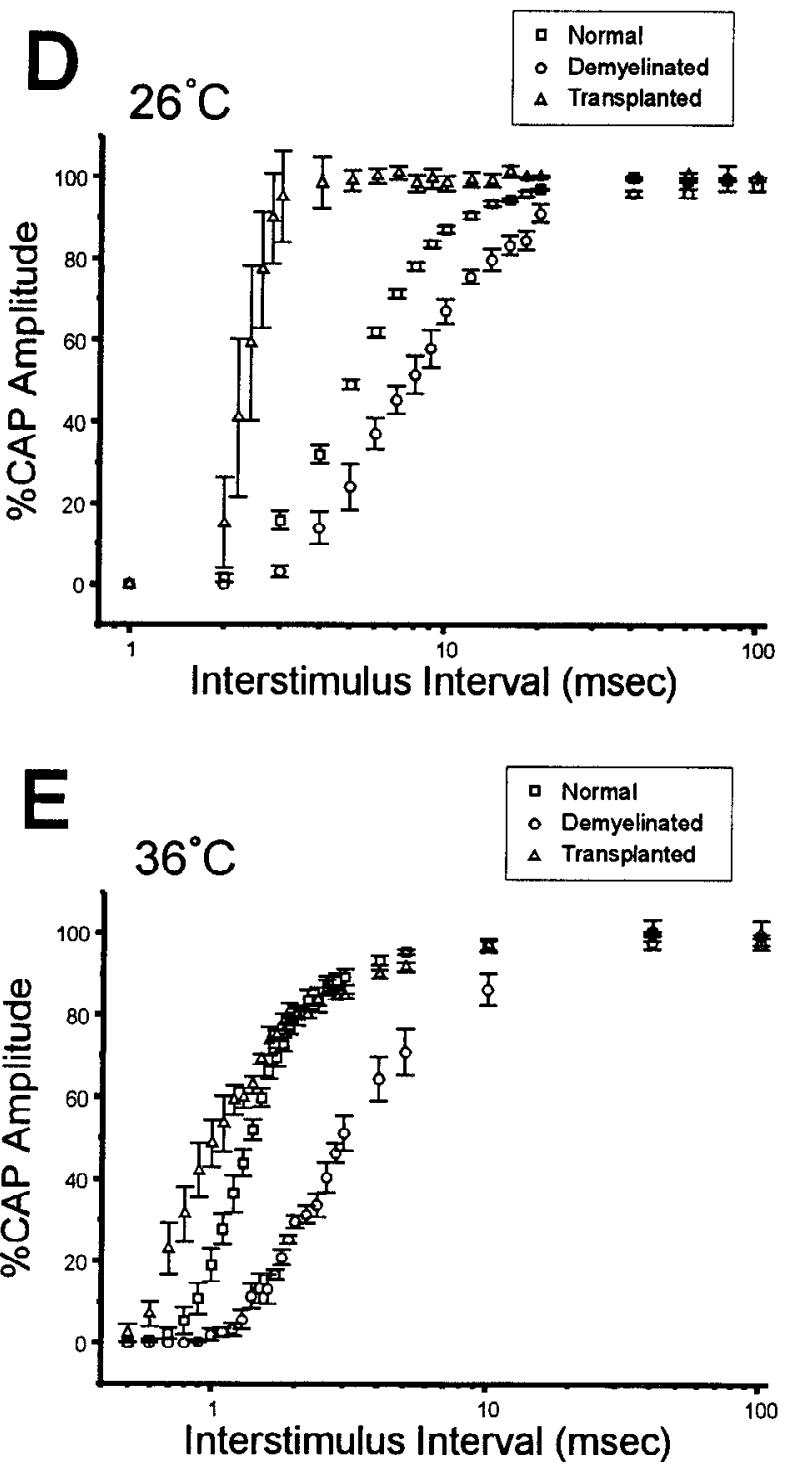

Figure 7. Paired-pulse stimuli at varying interstimulus intervals were applied to study the refractory period for transmission in normal $(A)$, demyelinated $(B)$, and transplant-induced $(C)$ remyelinated axons. Compound action potentials resulting from the second of two paired stimuli were plotted at increasing interstimulus intervals for three groups at $26^{\circ} \mathrm{C}(D)$ and $36^{\circ} \mathrm{C}(E)$. Amplitude recovery was reduced in the demyelinated axons compared with normal axons, but transplant-induced remyelinated axons exhibited faster recovery properties than control axons.

disease has also been considered, but limited laboratory work in cxpcrimental animal models cxamining the clcctrophysiological or functional consequences of such interventions has been performed. Whereas cultured oligodendrocyte progenitor cells can remyelinate demyelinated CNS axons, Schwann cells are also capable of myelinating CNS axons (Blakemore and Crang, 1985; Duncan et al., 1988). A potential advantage in the use of Schwann cells for transplantation is that they are derived from peripheral tissues and potentially could be derived from the same animal or patient (e.g., via sural nerve biopsy) with minimal adverse effects, thereby obviating problems of cell rejection and the necessity for immunosuppression. Moreover, Schwann cell remyelination of CNS axons in immunologically mediated CNS-demyelinating diseases may be resistant to further immunological attack.

In the model system used in the current study, introduction of Schwann cells alone into the EB-X lesion results in remyelination limited to a region near the injection site. However, as initially reported by Blakemore and colleagues (Blakemore ct al., 1987; Franklin et al., 1992), when a combination of Schwann cells and astrocytes is injected simultaneously, the Schwann cells displayed extensive migration and remyelinated virtually the entire demyelinated region. This suggests that some component of, or factor derived from, astrocytes is essential at the time of donor cell introduction into the host CNS to confer migratory and possibly myelinating potential to the Schwann cells (Blakemore and Crang, 1985). Future work to determine the molecular nature of the astrocytic influence on the Schwann cell's migratory potential will be needed if monocellular transplant approaches, using only Schwann cells, are to be developed.

Whereas the presence of cultured astrocytes together with the donor Schwann cells is critical for the achievement of cxtcnsive myelination of the EB-X lesion which is glial-free, introduction of Schwann cells alone or in combination with astrocytes does not result in myelin formation that is as extensive as the remyelination 
$26^{\circ} \mathrm{C}$

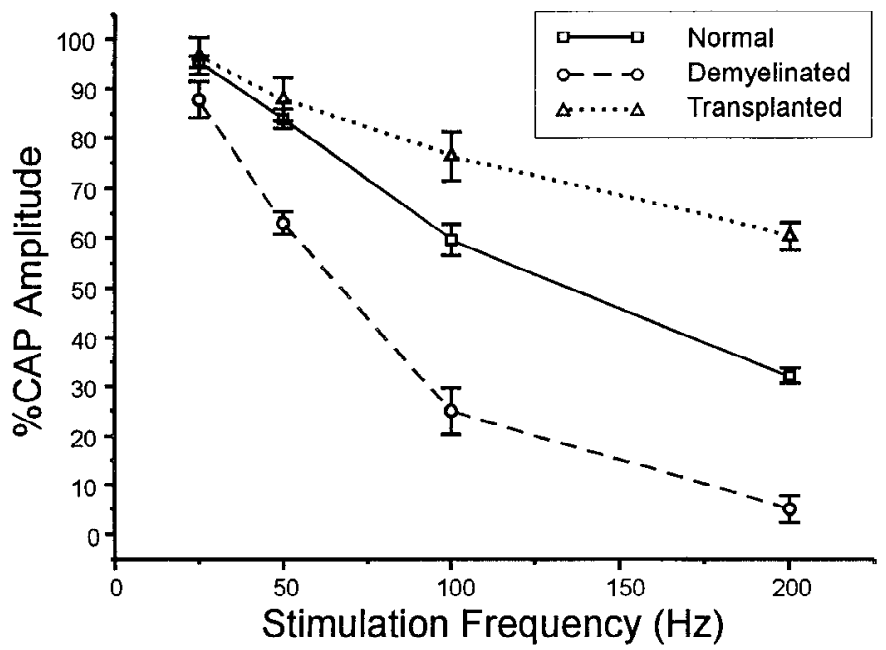

$36^{\circ} \mathrm{C}$

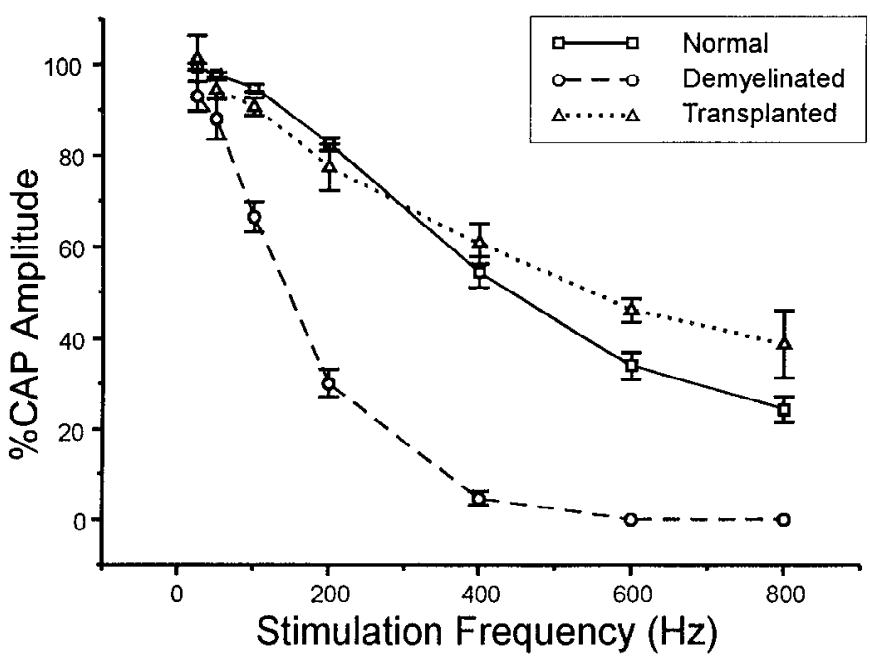

Figure 8. The compound action potential amplitudes of the last response of a train $\left(1 \mathrm{sec}, 26^{\circ} \mathrm{C} ; 0.5 \mathrm{sec}, 36^{\circ} \mathrm{C}\right)$, expressed as a percentage of the first response, were plotted at various frequencies. These frequency-response curves were plotted for normal, demyelinated, and transplant-induced remyelinated axons at 26 and $36^{\circ} \mathrm{C}$. The demyelinated axons showed reduced frequency-response properties. Transplantation-induced remyelinated axons showed less decrement in their frequency-response properties compared with those of the demyelinated axons; at higher frequencies, the remyelinated axons showed less amplitude decrement than controls.

in lesion models that contain resident astrocytes. For example, the $m d$ rat has virtually no endogenous CNS myelin, but the CNS is replete with astrocytes; introduction of Schwann cells and combinations of Schwann cells and astrocytes results in myelination of the $m d$ axons, but migration is more limited than in the glial-free environment of the EB-X lesion (Duncan et al., 1988). This suggests that resident astrocytes may impede the migration of Schwann cells. The most notable example of this is the glial limitans at the junction of spinal cord and PNS where an astrocytic layer prevents Schwann cell entry into the CNS (Sims et al., 1985). It is not clear whether extensive remyelination, as observed in the
EB-X lesion, will occur in more naturally occurring demyelinating disorders, in which astrocytes are present.

The axon membrane of normal myelinated fibers has a heterogeneous distribution of $\mathrm{Na}^{+}$channels along the longitudinal axis of the axon. $\mathrm{Na}^{+}$channels cluster at the node of Ranvier with a density of $\sim 1000 / \mu \mathrm{m}^{2}$ as compared with the internodal axon membrane, which has a $\mathrm{Na}^{+}$channel density of $\sim 25 / \mu \mathrm{m}^{2}$ (Ritchie and Rogart, 1977; Shrager 1989; Waxman, 1997). The mechanism for the clustering of nodal $\mathrm{Na}^{+}$channels at the node is not known, but is associated with axo-glial contact and precedes myelination (Waxman and Foster, 1980; WileyLivingston and Ellisman, 1980). Although anatomical myelination occurs after transplantation of myelin-forming precursor cells into the EB-X lesion, one could not assume, a priori, that the transplanted cells would interact with axons in the glial-free microenvironment in a manner that permits $\mathrm{Na}^{+}$channel clustering at the newly formed nodes of Ranvier so that channel densities appropriate for secure conduction would be achieved. Moreover, internodal distances, myelin thickness, and axon diameter along axons after endogenous remyelination are altered compared with normal (Harrison and McDonald, 1977), and these changes can lead to impedance mismatch that produces conduction block (Koles and Rasminsky, 1972; Waxman and Brill, 1978). These complex structural changes in remyelinated axons make it difficult to predict, a priori, the physiological effects of remyelination by transplanted cells.

Our results indicate that demyelinated axons of the adult mammalian CNS, remyelinated by transplantation of exogcnously derived Schwann cells, conduct action potentials in a manner similar to normal control myelinated axons. Conduction velocities of the transplant-induced remyelinated axons were similar to controls. This is consistent with observations that showed that the relationship between internode distance and conduction velocity is hyperbolic with a broad maximum (Huxley and Stampfli, 1949); reductions in internode distance of threefold or less, as observed in many remyelinated axons, would be expected to result in conduction velocities close 10 normal (Brill et al., 1977). The frequency-response properties of the remyelinated axons did, however, display enhanced frequency-response characteristics, compared with controls, over the same frequency ranges (Figs. 7, 8). The enhanced frequency-responsc properties after transplant-induced remyelination were unexpected. They may reflect differences in nodal geometry of Schwann cell- versus oligodendrocytemyelinated axons (Peters, 1966; Berthold, 1995) or in altered ionic homeostasis mechanisms at nodes of Ranvier along Schwann cell-remyelinated CNS axons after cell transplantation. It is well-established that the extracellular concentration of $\mathrm{K}^{+}$, which is regulated by glial cells, can influence axonal conduction properties in the CNS (Kocsis et al. 1983), and changes in axo-glial organization could affect axonal frequency-response properties. Moreover, conduction extended for a much greater longitudinal distance into the transplant zone as compared with the demyelinated axons, suggesting the overcoming of conduction block, and impulses can propagate past the transition zone between remyelinated and normally myelinated axon segments. These results indicate that sufficient nodal clustering of $\mathrm{Na}^{+}$channels occurs and appropriate internodal lengths arc established in the remyelinated axons to restore essentially normal conduction.

The restoration of conduction velocity and security of impulse conduction after remyelination by transplanted heterologous 
Schwann cells reported here indicates that an exogenous source of myelin-forming cells can elicit the formation of myelinated internodes and associated structures such as nodes of Ranvier that support secure impulse conduction in the host adult CNS. Thus, the present study indicates that the conduction properties of demyelinated axons in the adult mammalian spinal cord can be markedly improved after the transplantation of exogenous Schwann cells and astrocytes, indicating that demyelinated mammalian CNS white matter is amenable to not only anatomical, but also functional repair by transplantation of exogenous myelin-forming cells.

\section{REFERENCES}

Barrett EF, Barrett JN (1982) Intracellular recording from vertebrate myelinated axons: mechanism of the depolarizing afterpotential. J Physiol (Lond) 323:117-144.

Berthold C, Rydmark M (1995) Morphology of normal peripheral axons. In: The axon: structure, function and pathophysiology (Waxman SG, Kocsis JD, Stys PK, cds), pp 13-50. New York: Oxford UP.

Blakemore WF (1976) Invasion of Schwann cells into the spinal cord of the rat following local injections of lysolecithin. Neuropathol Appl Neurobiol 2:21-39.

Blakemore WF, Crang AJ (1985) The use of cultured autologous Schwann cells to remyelinate areas of persistent demyelination in the central nervous system. J Neurol Sci 70:207-223.

Blakemore WF, Franklin RJ (1991) Transplantation of glial cells into the CNS. Trends Neurosci 14:323-327.

Blakemore WF, Patterson RC (1978) Suppression of remyelination in the CNS by $x$ irradiation. Acta Neuropathol (Berl) 42:105-113.

Blakemore WF, Eames RA, Smith KJ, McDonald WI (1977) Remyelination in the spinal cord of the cat following intraspinal injections of lysolecithin. J Neurol Sci 33:31-43.

Blakemore WF, Crang AJ, Patterson RC (1987) Schwann cell remyelination of CNS axons following injection of cultures of CNS cells into areas of persistent demyelination. Neurosci Lett 77:20-24.

Blight AR (1983) Axonal physiology of chronic spinal cord injury in the cat: intracellular recording in vitro. Neuroscience 10:1471-1486.

Blight AR, Someya S (1985) Depolarizing afterpotentials in myelinated axons of mammalian spinal cord. Neuroscience 15:1-12.

Blight AR, Young W (1989) Central axons in injured cat spinal cord recover electro-physiological function following remyelination by Schwann cells. J Neurol Sci 91:15-34.

Brill MH, Waxman SG, Moore JW, Joyner RW (1977) Conduction velocity and spike configuration in myelinated fibres: computed dependence on internode distance. J Neurol Neurosurg Psychiatry 40:769-774.

Brockes JP, Fields KL, Raff MC (1979) Studies on cultured rat Schwann cells. I. Establishment of purified populations from cultures of peripheral nerve. Brain Res 165:105-118.

Bunge RP, Puckett WR, Becerra JL, Marcillo A, Quencer RM (1993) Observations on the pathology of human spinal cord injury. A review and classification of 22 new cases with details from a case of chronic cord compression with extensive focal demyelination. In: Advances in neurology: neural injury and regeneration, Vol 59 (Seil FJ, ed), pp 75-89. New York: Raven.

Byrne TN, Waxman SG (1990) Spinal cord compression. Philadelphia: Davis.

Clifford-Jones RE, Landon DN, McDonald WI (1980) Remyelination during optic nerve compression. J Neurol Sci 46:239-243.

Duncan ID, Hammang JP, Jackson KF, Wood PM, Bunge RP, Langford L (1988) Transplantation of oligodendrocytes and Schwann cells into the spinal cord of the myelin-deficient rat. J Neurocytol 17:351-360.

Felts PA, Smith KJ (1992) Conduction properties of central nerve fibers remyelinated by Schwann cells. Brain Res 574:178-192.

Franklin RJM, Crang AJ, Blakemore WF (1992) Type-1 astrocytes fail to inhibit Schwann cell remyelination of CNS axons in the absence of cells of the o-2a lineage. Dev Neurosci 14:85-92.

Ghatak NR, Hirano A, Doron Y, Zimmerman HM (1973) Remyelination in multiple sclerosis with peripheral type myelin. Arch Neurol 29:262-267.

Gledhill RF, McDonald WI (1977) Morphological characteristics of central demyelination and remyelination: a single-fiber study. Ann Neurol $522-560$.

Gledhill RF, Harrison BM, McDonald WI (1973) Pattern of remyelination in the CNS. Nature 244:443-444.
Gout O, Dubois-Dalcq M (1993) Directed migration of transplanted glial cells toward a spinal cord demyelinating lesion. Int J Dev Neurosci 11:613-623.

Groves AK, Barnett SC, Franklin RJ, Crang AJ, Mayer M, Blakemore WF, Noble M (1993) Repair of demyelinated lesions by transplantation of purified O-2A progenitor cells. Nature 362:453-455.

Harrison BM, McDonald WI (1977) Remyelination after transient experimental compression of the spinal cord. Ann Neurol 1:542-551.

Hines M, Shrager P (1991) A computational test of the requirements for conduction in demyelinated axons. Rest Neurol Neurosci 3:81-93.

Honmou O, Utzschneider DA, Rizzo MA, Bowe CM, Waxman SG, Kocsis JD (1994) Delayed depolarization and slow sodium currents in cutaneous afferents. J Neurophysiol 71:1627-1637.

Huxley AF, Stämpfli R (1949) Evidence for saltatory conduction in peripheral myelinated nerve fibres. J Physiol (Lond) 108:315-339.

Itoyama Y, Ohnishi A, Tateishi J, Kuroiwa Y, Webster HD (1985) Spinal cord multiple sclerosis lesions in Japanese patients: Schwann cell remyelination occurs in areas that lack glial fibrillary acidic protein (GFAP). Acta Neuropathol (Berl) 65:217-223.

Kapoor R, Smith KJ, Felts PA, Davies M (1993) Internodal potassium currents can generate ectopic impulses in mammalian myelinated axons. Brain Res 611:165-169.

Kocsis JD, Waxman SG (1980) Absence of potassium conductance in central myelinated axons. Nature 287:348-349.

Kocsis JD, Waxman SG (1982) Intra-axonal recordings in rat dorsal column axons: membrane hyperpolarization and decreased excitability precede the primary afferent depolarization. Brain Res 238:222-227.

Kocsis JD, Malenka RC, Waxman SG (1983) Effects of extracellular potassium concentration on the excitability of the parallel fibres of the rat cerebellum. J Physiol (Lond) 334:225-244.

Koles ZJ, Rasminsky M (1972) A computer simulation of conduction in demyelinated nerve fibres. J Physiol (Lond) 227:351-364.

Lachapelle F, Duhamel-Clerin E, Gansmuller A, Baron-Van Evercooren A, Villarroya H, Gumpel M (1994) Transplanted transgenically marked oligodendrocytes survive, migrate and myelinate in the normal mouse brain as they do in the shiverer mouse brain. Eur J Neurosci 6:814-824.

Levi AD, Bunge RP (1994) Studies of myelin formation after transplantation of human Schwann cells into the severe combined immunodeficient mouse. Exp Neurol 130:41-52.

Lindvall O, Sawle G, Widner H, Rothwell JC, Bjorklund A, Brooks D, Brundin P, Frackowiak R, Marsden CD, Odin P, Rehncrona S (1994) Evidence for long-term survival and function of dopaminergic grafts in progressive Parkinson's disease. Ann Neurol 35:172-180.

Mann R, Mulligan RC, Baltimore D (1983) Construction of a retrovirus packaging mutant and its use to produce helper-free defective retrovirus. Cell 33:153-159.

McCarthy KD, de Vellis J (1980) Preparation of separate astroglial and oligodendroglial cell cultures from rat cerebral tissue. J Cell Biol 85:890-902.

McDonald WI (1995) Overview of clinical aspects of multiple sclerosis, including cognitive deficit. In: The axon: structure, function and pathophysiology (Waxman SG, Kocsis JD, Stys PK, cds), pp 661-668. Ncw York: Oxford UP.

Moore JW, Joyner RW, Brill MH, Waxman SG, Najar-Joa M (1978) Simulations of conduction in uniform myelinated fibres: relative sensitivity to changes in nodal and internodal parameters. Biophys J 21:147-161.

Peters A (1966) The node of Ranvier in the central nervous system. Q J Exp Physiol Cogn Med Sci 51:229-236.

Porter S, Blairclark M, Glaser L, Bunge RP (1986) Schwann cells stimulated to proliferate in the absence of neurons retain full functional capability. J Neurol Sci 6:3070-3078.

Price J, Turner D, Cepko C (1987) Lineage analysis in the vertebrate nervous system by retrovirus-mediated gene transfer. Proc Natl Acad Sci USA 84:156-160.

Prineas J, Connell F (1979) Remyelination in multiple sclerosis. Ann Neurol 5:22-31.

Ritchie JM, Rogart RB (1977) Density of sodium channels in mammalian myelinated nerve fibers and nature of the axonal membrane under the myelin sheath. Proc Natl Acad Sci USA 74:211-215.

Rosenbluth J, Hasegawa M, Shirasaki N, Rosen CL, Liu Z (1990) Myelin formation following transplantation of normal fetal glia into myelindeficient rat spinal cord. J Neurocytol 19:718-730.

Shrager P (1989) Sodium channels in single demyelinated mammalian axons. Brain Res 483:149-154. 
Sims TJ, Gilmorc SA, Waxman SG, Klinge E (1985) Dorsal-ventral differences in the glia limitans of the spinal cord: an ultrastructural study in developing normal and irradiated rats. $\mathbf{J}$ Neuropathol Exp Neurol 44:415-429.

Smith KJ, Blakemore WF, McDonald WI (1979) Central remyelination restores securc conduction. Nature 280:395-396.

Smith KJ, Blakemore WF, McDonald WI (1981) The restoration of conduction by central remyelination. Brain 104:383-404.

Utzschneider DA, Archer DR, Kocsis JD, Waxman SG, Duncan ID (1994) Transplantation of glial cells cnhances action potential conduction of amyelinated spinal cord axons in the myelin-deficient rat. Proc Natl Acad Sci USA 91:53-57.

Vignais L, Nait Oumesmar B, Mellouk F, Gout O, Labourdette G, Baron-Van Evercooren A, Gumpel M (1993) Transplantation of oli- godendrocytc precursors in the adult demyelinated spinal cord: migration and remyelination. Int J Dev Neurosci 11:603-612.

Waxman SG (1977) Conduction in myelinated, unmyelinated, and demyelinated fibers. Arch Neurol 34:585-589.

Waxman SG, Brill MH (1978) Conduction through demyelinated plaques in multiple sclerosis: computer simulations of facilitation by short internodes. J Neurol Neurosurg Psychiatry 41:408-417.

Waxman SG, Fostcr RE (1980) Development of the axon membrane during differentiation of myelinated fibres in spinal nerve roots. Proc $\mathrm{R}$ Soc Lond [Biol] 209:441-446.

Wiley-Livingston C, Ellisman MH (1980) Development of axonal membrane specializations defines nodes of Ranvier and precedes Schwann cell myelin elaboration. Dev Biol 79:334-355. 